О.В. Кравець О.О. Колеснік, В.В. Чернієнко О.В. Хлинін

\title{
Реконструктивно-відновні операції у хворих на місцево-поширений плоскоклітинний рак слизової оболонки дна ротової порожнини та щоки
}

\author{
Національний інститут раку, Київ \\ Одержано: 9.06.2020 \\ Прийнято до друку: 6.07.2020 \\ DOI: 10.32471/clinicaloncology.2663-466X.37-1.26994
}

\begin{abstract}
Мета. Порівняти функціональний результат та якість життя хворих на місцево-поширений плоскоклітинний рак ротової порожнини при застосуванні різних реконструктивно-відновних методик для заміщення післяопераційних дефектів дна ротової порожнини та щоки. Матеріали і методи. Проведено порівняльний аналіз результатів оперативних втручань, виконаних 150 пацієнтам з місцево-поширеним плоскоклітинним раком слизової оболонки дна ротової порожнини та щоки. Типи дефектів після видалення первинної пухлини: поверхневий дефект дна ротової порожнини в 29 хворих, глибокий дефект дна ротової порожнини у 65, середній та великий дефекти слизової оболонки щоки - у 56 пацієнтів. Результати. У разі пластичного заміщення поверхневих дефектів дна ротової порожнини встановлено вірогідно $(p=0,006)$ вищий функціональний результат за показником повноцінності дієти у групі хворих, яким було застосовано шкірно-м'язовий клапоть платизми порівняно з групою хворих, у яких було використано носогубний клапоть $(75,7 \pm 13,4 \%$ та $60,8 \pm 9,0 \%$ відповідно) та за показником харчування на людях $(p=0,04)$ у групі хворих, у яких було використано шкірно-м'язовий клапоть платизми порівняно з групою носогубного клаптя (80,4 $14,5 \%$ та $68,8 \pm 11,3 \%$ відповідно). У разі пластичного заміщення глибоких дефектів дна ротової порожнини встановлено вірогідно $(p<0,001)$ вищий функціональний результат за показником повноцінності дієти у групі хворих, у яких було використано шкірно-м'язовий клапоть великого грудного м'яза порівняно 3 групою хворих, у яких було застосовано шкірно-м'язовий клапоть кивального м'яза $(56,9 \pm 9,3 \%$ та $44 \pm 8,2 \%$ відповідно) та за показником харчування на людях $(p=0,005)$ у хворих групи шкірно-м'язового клаптя великого грудного м'яза порівняно з групою шкірно-м'язового клаптя кивального м'яза $(72,4 \pm 12,2 \%$ та $62 \pm 12,7 \%$ відповідно). У разі пластичного заміщення дефектів слизової оболонки щоки встановлено вірогідно $(p=0,007)$ вищий функціональний результат за показником повноцінності дієти у групі хворих, у якій використано шкірні клапті порівняно з групою хворих, яким застосовано фасціальні

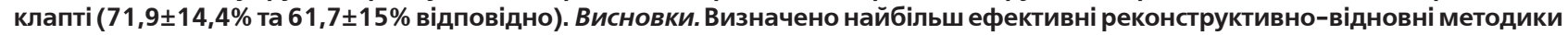
для пластичного заміщення післяопераційних поверхневих і глибоких дефектів дна ротової порожнини та щоки.
\end{abstract}

Ключові слова: місцево-поширений плоскоклітинний рак слизової дна ротової порожнини та щоки; реконструктивно-відновне лікування; клапті.

\section{вступ}

Лікування хворих на місцево-поширений плоскоклітинний рак слизової оболонки дна ротової порожнини та щоки передбачає хірургічне втручання з наступною променевою або одночасною хіміопроменевою терапією [1].

Місцево-поширений плоскоклітинний рак слизової оболонки дна ротової порожнини та щоки є показанням до виконання комбінованих і розширених втручань, що призводить до значних функціональних порушень мовлення, ковтання, жування, дихання та косметичних дефектів обличчя, тому проведення одночасних реконструктивно-відновних операцій $€$ невід'ємною складовою лікування даної категорії хворих. У переважній більшості досліджень, у яких вивчали функціональний статус та якість життя хворих після реконструктивних втручань, оцінювали всі дефекти ротової порожнини в цілому, а не конкретний дефект, що не дає можливості визначити переваги тієї чи іншої реконструктивної методики [2].

Пластичне усунення поверхневих дефектів дна ротової порожнини проводять регіонарними шкірно-м'язовими клаптями платизми (ШМКП) та носогубними клаптями (НГК), а глибоких дефектів - регіонарними шкірно-м'язовими клаптями кивального м'яза (ШМККМ) та шкірно-м'язовими клаптями великого грудного м’яза (ШМКВГМ). Загалом високі показники завершеності первинної пластики та гарні функціональні результати отримані при використанні вищезазначених регіонарних клаптів як при заміщенні поверхневих, так і глибоких дефектів дна ротової порожнини [3-8]. Проте порівняння ефективності застосування НГК та ШМКП для заміщення поверхневих дефектів дна ротової порожнини і ШМККМ та ШМКВГМ для усунення глибоких дефектів дотепер не проводилося.
У міжнародній літературі відсутні чіткі рекомендації щодо вибору реконструктивної методики для заміщення дефектів слизової оболонки щоки. Реконструкція щоки після видалення злоякісних новоутворень слизової оболонки може бути проведена фасціальними клаптями (ФК) (клапоть жирового тіла щоки (КЖТЩ), фасціально-апоневротичним скронево-тім'яним клаптем (ФАСТК)) та шкірними клаптями (ШК) (ШМКП, клапоть надключичної артерії (КНА) [9-14]. Відсутні дані щодо порівняння ефективності застосування ФК та ШК для заміщення післяопераційних дефектів слизової щоки.

\section{МЕТА ДОСЛІДЖЕННЯ}

Порівняти функціональний результат та якість життя хворих на місцево-поширений плоскоклітинний рак ротової порожнини при застосуванні різних реконструктивно-відновних методик для заміщення післяопераційних дефектів дна ротової порожнини та щоки.

\section{МАТЕРІАЛИ ТА МЕТОДИ ДОСЛІДЖЕННЯ}

Проведено порівняльний аналіз результатів оперативних втручань, виконаних 150 пацієнтам з місцево-поширеним плоскоклітинним раком слизової оболонки дна ротової порожнини та щоки, що перебували на лікуванні у відділенні пухлин голови та шиї Національного інституту раку у період 2010-2018 pp. Чоловіків було 134 (89,3\%), жінок - 16 (10,7\%). Стадію III (T2N1M0, T3N0-1M0) діагностовано у $88(58,7 \%)$ пацієнтів, стадію IV (T2-3N2M0, T4N1-2M0) - у $62(41,3 \%)$ хворих.

Усім пацієнтам проведено хірургічне лікування в обсязі видалення первинної пухлини, шийної лімфодисекції, реконструкції дна ротової порожнини та щоки. Пацієнти були 
поділені на групи залежно від типу післяопераційного дефекту після видалення первинної пухлини. Виділено групи пацієнтів з наступними типами дефектів: поверхневий дефект дна ротової порожнини (зі збереженням щелепно-під'язикового м'яза) у $29(19,3 \%)$ хворих, глибокий дефект дна ротової порожнини (з резекцією щелепно-під'язикового та інших надпід'язикових м'язів) - у 65 (43,3,8\%), середній (від 3 до 6 см у найбільшому вимірі) та великий (більше 6 см у найбільшому вимірі) дефекти слизової оболонки щоки - у $56(37,4 \%)$ випадках.

Пластичне заміщення поверхневих дефектів дна ротової порожнини із застосуванням НГК (група НГК) виконано у 14 пацієнтів, пластичне замішення поверхневих дефектів дна ротової порожнини із застосуванням модифікованого ШМКП (група ШМКП) - у 15 хворих.

Пластичне усунення глибоких дефектів дна ротової порожнини із застосуванням ШМККМ (група ШМККМ) виконано у 31 пацієнта, пластичне усунення глибоких дефектів дна ротової порожнини із застосуванням модифікованого ШМКВГМ (група ШМКВГМ) - у 34 хворих.

У 26 пацієнтів проведено реконструкцію щоки із застосуванням фасціальних клаптів - КЖТЩ та ФАСТК (група ФК), у 30 хворих - із застосуванням шкірних клаптів - модифікованого ШМКП та КНА (група ШК). У групі ФК середні дефекти слизової оболонки щоки після видалення первинної пухлини заміщали КЖТЩ, великі - ФАСТК. У групі ШК середні дефекти слизової оболонки щоки після видалення первинної пухлини заміщали ШМКП, великі - КНА.

Критерії включення хворих до дослідження:

- хворі з резектабельним плоскоклітинним раком слизової оболонки дна ротової порожнини та щоки III-IV стадій, яким виконано хірургічне втручання з пластичним заміщенням дефекту васкуляризованим клаптем.

Критерії виключення з дослідження:

- відмова пацієнта від участі в дослідженні;

- наявність віддалених метастазів;

- інше злоякісне новоутворення в анамнезі;

- проведена перед оперативним втручанням променева або хіміопроменева терапія;

- тяжка супутня патологія, визначена як протипоказання до проведення реконструктивної операції.

НГК, КЖТЩ, ФАСТК та КНА виділяли за загальноприйнятою методикою. Модифікований ШМКП виділяли наступним чином: ніжку клаптя маркували на 1,5-2 см нижче нижнього краю нижньої щелепи, а шкірну частину, відповідно до розмірів дефекту, вертикально до ключиці; дисекцію виконували включаючи в склад клаптя шкіру, поверхневий жировий шар, підшкірний м'яз, глибокий жировий шар, фасцію кивального м'яза; зберігали субментальну артерію і вену (якщо це було можливо при проведенні шийної дисекціі), лицеву артерію і вену; зовнішню яремну вену перев'язували і перетинали у надключичній ділянці та включали у склад клаптя; з шкірної частини клаптя, яка при його транспозиції буде знаходитися в тунелі, видаляли лише епідерміс для збереження внутрішньодермального судинного сплетення, що дозволило забезпечити його кровопостачання з двох джерел: артеріальних перфорантів судинного сплетення глибокого жирового шару та внутрішньодермального судинного сплетення; транспозицію клаптя проводили субмандибулярно (для реконструкції дна ротової порожнини) або супрамандибулярно (для реконструкції шоки).

Модифікований ШМКВГМ виділяли в такий спосіб: шкірну частину клаптя окреслювали горизонтально під сосково-ареолярним комплексом; прикріплення грудного м'яза до ребер та нижньої частини грудини перетинали; дисекцію клаптя проводили в дистально-проксимальному напрямку між великим та малим грудними м'язами послідовно перетинаючи м'язові волокна; треті міжреберні перфоранти внутрішньої грудної артерії включали у клапоть, перев'язуючи та перетинаючи їх безпосередньо в місці виходу з грудної стінки; м'язові волокна великого грудного м'яза перетинали горизонтально, у місці, де чітко ідентифікуються кінцеві відділи грудної гілки торако-акроміальної артерії, зберігаючи цілісність його ключичної та частково грудинно-ребрової частин; судинну «ніжку» виділяли селективно під збереженою частиною м'яза до місця iіi відходження від пахвових судин; після перев'язки перфорантів торако-акоміальної артерії до ключичної частини м'яза перетинали ключично-грудну фасцію, горизонтально розтинали грудний м'яз під ключицею та формували тунель; транспозицію клаптя до дефекту проводили через підм'язовий тунель на передній грудній стінці, над ключицею та підшкірний тунель на шиї.

Порівнювали функціональний статус та якість життя хворих. Функціональний статус вивчали за шкалою функціонування для хворих на рак голови та шиї (Performance Status Scale for Head and Neck Cancer Patients - PSS-HN) через 6 та 12 міс після хірургічного лікування. Якість життя оцінювали за опитувальником якості життя Вашингтонського Університету (University of Washington Quality of Life questionnaire, version 4 - UW-QOL v4) через 6 та 12 міс після хірургічного лікування.

Статистичний аналіз результатів дослідження проводився в пакеті MedCalc v. 18.11 (MedCalc Software bvba, Бельгія, 1993-2018 pp.).

Для представлення кількісних ознак розраховували середнє значення показника $(\overline{\mathrm{X}})$ та його середньоквадратичне відхилення $( \pm \mathrm{SD})$, якісних - частоту ознаки $(\%)$. Кількісні ознаки порівнювали з використанням критерію Стьюдента (у разі нормального закону розподілу) або критерію Вілкоксона (W) (у разі закону розподілу, відмінного від нормального). Розподіл на нормальність перевіряли за критерієм Шапіро - Уілка. Для порівняння якісних показників використовували критерій хі-квадрат (з урахуванням поправки Йєйтса). Для оцінки клінічного ефекту розраховували його величину та $95 \%$ довірчий інтервал (ДІ). Критичним рівнем значущості вважали $\alpha_{\text {кр. }}=0,05$.

\section{РЕЗУЛЬТАТИ}

Пластичне усунення поверхневих дефектів дна ротової порожнини. Статистично значущих відмінностей між групою НГК та групою ШМКП за віком, статтю, ТNM, стадією захворювання, ад'ювантним лікуванням не встановлено ( $>0,05$ для всіх порівнянь).

У дослідженні встановлено вірогідно ( $\mathrm{p}=0,006)$ вищий функціональний результат за показником повноцінності дієти шкали PSS-HN через 12 міс після хірургічного лікування у хворих групи ШМКП порівняно з групою НГК $(75,7 \pm 13,4 \%$ та $60,8 \pm 9,0 \%$ відповідно) та вірогідно ( $\mathrm{p}=0,04)$ вищий функціональний результат за показником харчування на людях у хворих групи ШМКП порівняно з групою НГК $(80,4 \pm 14,5 \%$ та $68,8 \pm 11,3 \%$ відповідно). Статистично значущих відмінностей за показником зрозумілості мови шкали PSS-HN між групами хворих не виявлено ( $>0,05)$. Результат пластичного заміщення поверхневого дефекту дна ротової порожнини модифікованим ШМКП представлено на рис. 1.

При проведенні порівняльного аналізу якості життя за опитувальником UW-QOL v4 через 12 міс після хірургічного лікування було виявлено вірогідно $(\mathrm{p}=0,02)$ вище значення показника зовнішнього вигляду у хворих групи ШМКП порівняно з групою НГК $(82,1 \pm 11,7 \%$ та $70,8 \pm 9,7 \%$ відповідно) та вірогідно $(\mathrm{p}=0,03)$ вище значення показника жування у хворих групи ШМКП порівняно з групою НГК

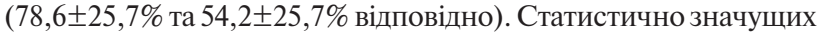
відмінностей за показниками болю, активності, відпочинку, мови, плеча, смаку, слини, настрою, занепокоєння та загальних питань опитувальника UW-QOL v4 між групами хворих не встановлено (p>0,05 для всіх порівнянь) (табл. 1).

Пластичне усунення глибоких дефектів дна ротової порожнини. Статистично значущих відмінностей між групою ШМККМ та групою ШМКВГМ за віком, статтю, ТNM, стадією захворювання, ад'ювантним лікуванням не встановлено ( $\mathrm{p}>0,05$ для усіх порівнянь).

Встановлено вірогідно $(\mathrm{p}<0,001)$ вищий функціональний результат за показником повноцінності дієти шкали PSS-HN через 
12 міс після хірургічного лікування у хворих групи ШМКВГМ

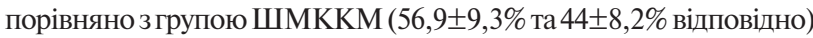
та вірогідно $(\mathrm{p}=0,005)$ вищий функціональний результат за показником харчування на людях у хворих групи ШМКВГМ порівняно з групою ШМККМ (72,4 $\pm 12,2 \%$ та $62 \pm 12,7 \%$ відповідно). Статистично значущих відмінностей за показником зрозумілості мови шкали PSS-HN між групами хворих не виявлено (p>0,05). Результат пластичного заміщення глибокого дефекту дна ротової порожнини модифікованим ШМКВГМ представлено на рис. 2.

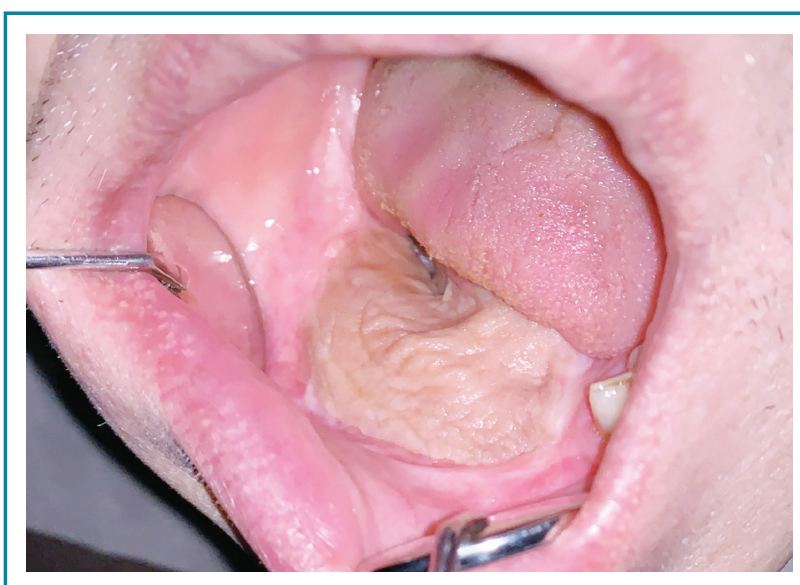

Рис. 1. Пластичне заміщення поверхневого дефекту дна ротової порожнини модифікованим ШМКП
При проведенні порівняльного аналізу якості життя за опитувальником UW-QOL v4 через 12 міс після хірургічного лікування було встановлено: вірогідно $(\mathrm{p}=0,01)$ вище значення показника зовнішнього вигляду у хворих групи ШМКВГМ порівняно з групою ШМККМ $(68,1 \pm 11,4 \%$ та $57 \pm 17 \%$ відповідно); вірогідно ( $\mathrm{p}=0,01)$ вище значення показника жування у хворих групи ШМКВГМ порівняно з групою ШМККМ $(56,9 \pm 17,5 \%$ та $44 \pm 16,6 \%$ відповідно); вірогідно $(\mathrm{p}<0,001)$ вище значення показника настрою у хворих групи ШМКВГМ

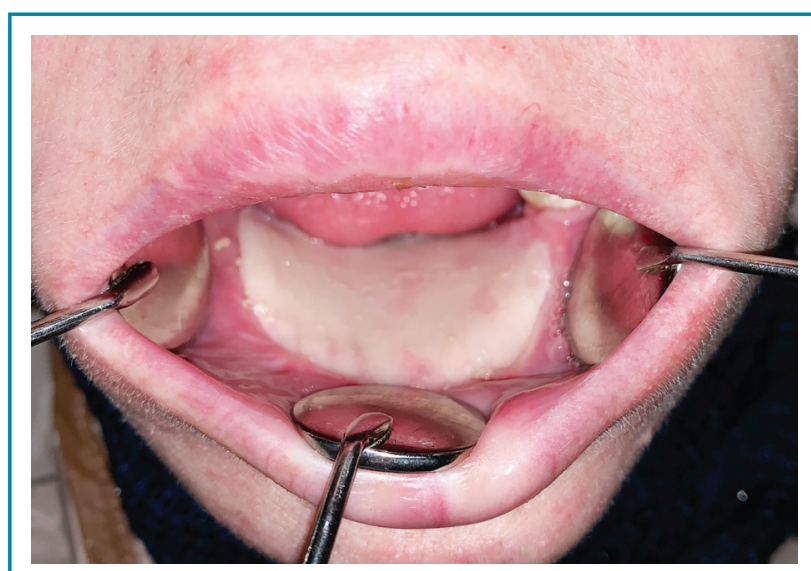

Рис. 2. Пластичне заміщення глибокого дефекту дна ротової порожнини модифікованим ШМКВГМ

Таблиця 1. Якість життя пацієнтів через 6 та 12 міс після хірургічного лікування

\begin{tabular}{|c|c|c|c|c|c|c|}
\hline \multirow{3}{*}{$\begin{array}{c}\text { Якість життя } \\
\text { за опитувальником } \\
\text { UW-QOL v4,\% }\end{array}$} & \multicolumn{4}{|c|}{$\overline{\mathrm{X}}_{ \pm \text {SD }}$} & \multirow{2}{*}{\multicolumn{2}{|c|}{$\begin{array}{c}\text { Рівень значимості відмінності між } \\
\text { групами, p }\end{array}$}} \\
\hline & \multicolumn{2}{|c|}{ Група НГК } & \multicolumn{2}{|c|}{ Група ШМКП } & & \\
\hline & $\begin{array}{c}\text { Через } 6 \text { міс } \\
(n=14)\end{array}$ & $\begin{array}{c}\text { Через } 12 \text { міс } \\
(n=12)\end{array}$ & $\begin{array}{c}\text { Через } 6 \text { міс } \\
(n=15)\end{array}$ & $\begin{array}{c}\text { Через } 12 \text { міс } \\
(n=14)\end{array}$ & Через 6 міс & Через 12 міс \\
\hline Біль & $82,1 \pm 18,2$ & $87,5 \pm 13,1$ & $81,7 \pm 14,8$ & $83,9 \pm 12,4$ & 0,85 & 0,47 \\
\hline Зовнішній вигляд & $71,4 \pm 9,1$ & $70,8 \pm 9,7$ & $81,7 \pm 11,4$ & $82,1 \pm 11,7$ & 0,02 & 0,02 \\
\hline Активність & $85,7 \pm 12,8$ & $87,5 \pm 13,1$ & $88,3 \pm 12,9$ & $91,1 \pm 12,4$ & 0,58 & 0,47 \\
\hline Відпочинок & $83,9 \pm 12,4$ & $85,4 \pm 12,9$ & $90 \pm 12,7$ & $89,3 \pm 12,8$ & 0,2 & 0,44 \\
\hline Ковтання & $85,7 \pm 12,8$ & $83,3 \pm 12,3$ & $86,7 \pm 12,9$ & $89,3 \pm 12,8$ & 0,84 & 0,23 \\
\hline Жування & $57,1 \pm 26,7$ & $54,2 \pm 25,7$ & $80 \pm 25,4$ & $78,6 \pm 25,7$ & 0,03 & 0,03 \\
\hline Мова & $85 \pm 15,6$ & $85 \pm 15,7$ & $92 \pm 13,7$ & $93,6 \pm 12,8$ & 0,2 & 0,13 \\
\hline Плече & $87,1 \pm 15,4$ & $87,5 \pm 15,4$ & $82 \pm 15,2$ & $80,7 \pm 14,9$ & 0,36 & 0,26 \\
\hline Смак & $55,7 \pm 19,9$ & $56,7 \pm 19,7$ & $56,7 \pm 19,5$ & $64,3 \pm 14,5$ & 0,89 & 0,26 \\
\hline Слина & $47,9 \pm 24,2$ & $53,3 \pm 20,6$ & $47,3 \pm 26,9$ & $53,6 \pm 24,1$ & $>0,99$ & 0,88 \\
\hline Настрій & $71,4 \pm 16,6$ & $75 \pm 15,1$ & $78,3 \pm 8,8$ & $82,1 \pm 11,7$ & 0,16 & 0,2 \\
\hline Занепокоєння & $74,3 \pm 10,9$ & $72,5 \pm 8,7$ & $78 \pm 13,7$ & $78,6 \pm 14,1$ & 0,42 & 0,2 \\
\hline Загальні питання: А & $51,8 \pm 6,7$ & $54,2 \pm 9,7$ & $55 \pm 10,4$ & $57,1 \pm 11,7$ & 0,32 & 0,48 \\
\hline B & $50 \pm 10,4$ & $51,7 \pm 10,3$ & $57,3 \pm 7$ & $57,1 \pm 7,3$ & 0,04 & 0,12 \\
\hline C & $52,9 \pm 12,7$ & $53,3 \pm 13$ & $60 \pm 13,1$ & $61,4 \pm 12,3$ & 0,14 & 0,11 \\
\hline
\end{tabular}

Примітка: А - У порівнянні з місяцем до того, як у Вас виявили рак, як би Ви оцінили стан здоров'я? В - Як би Ви оцінили стан Вашого здоров'я протягом останніх 7 днів? С - Загальна якість життя протягом останніх 7 днів.

Таблиця 2. Якість життя пацієнтів через 6 та 12 міс після хірургічного лікування

\begin{tabular}{|c|c|c|c|c|c|c|}
\hline \multirow{3}{*}{$\begin{array}{c}\text { якість життя } \\
\text { за опитувальником } \\
\text { UW-QOL v4,\% }\end{array}$} & \multicolumn{4}{|c|}{$\overline{\mathrm{X}}_{ \pm \text {SD }}$} & \multirow{2}{*}{\multicolumn{2}{|c|}{$\begin{array}{c}\text { Рівень значимості відмінності між } \\
\text { групами, } \mathrm{p}\end{array}$}} \\
\hline & \multicolumn{2}{|c|}{ Група ШМККМ } & \multicolumn{2}{|c|}{ Група ШМКВГМ } & & \\
\hline & $\begin{array}{c}\text { Через } 6 \text { міс } \\
(n=31)\end{array}$ & $\begin{array}{c}\text { Через } 12 \text { міс } \\
(n=25)\end{array}$ & $\begin{array}{c}\text { Через } 6 \text { міс } \\
(n=34)\end{array}$ & $\begin{array}{c}\text { Через } 12 \text { міс } \\
(n=29)\end{array}$ & Через 6 міс & Через 12 міс \\
\hline Біль & $70,2 \pm 16,4$ & $72 \pm 19,5$ & $69,9 \pm 17,2$ & $73,3 \pm 18,8$ & 0,91 & 0,79 \\
\hline Зовнішній вигляд & $62,1 \pm 16,9$ & $57 \pm 17$ & $72,1 \pm 11,9$ & $68,1 \pm 11,4$ & 0,01 & 0,01 \\
\hline Активність & $71 \pm 15,9$ & $74 \pm 13,5$ & $72,1 \pm 14,8$ & $75,9 \pm 12,5$ & 0,75 & 0,6 \\
\hline Відпочинок & $68,5 \pm 11,1$ & $69 \pm 14,9$ & $70,6 \pm 9,7$ & $72,4 \pm 10,2$ & 0,43 & 0,27 \\
\hline Ковтання & $69,2 \pm 15,3$ & $72,4 \pm 13,7$ & $74,6 \pm 13,4$ & $77,6 \pm 7,7$ & 0,09 & 0,12 \\
\hline Жування & $43,5 \pm 17$ & $44 \pm 16,6$ & $55,9 \pm 16,4$ & $56,9 \pm 17,5$ & 0,01 & 0,01 \\
\hline Мова & $67,1 \pm 21,5$ & $71,6 \pm 16,8$ & $72,4 \pm 20,2$ & $77,9 \pm 16,8$ & 0,31 & 0,16 \\
\hline Плече & $75,2 \pm 17,9$ & $71,2 \pm 19,6$ & $70,6 \pm 18,9$ & $69,7 \pm 19,7$ & 0,32 & 0,77 \\
\hline Смак & $53,2 \pm 20,1$ & $63,6 \pm 15$ & $54,7 \pm 19,7$ & $64,5 \pm 14$ & 0,76 & 0,82 \\
\hline Слина & $48,1 \pm 26,3$ & $60,4 \pm 17,4$ & $47,6 \pm 25,7$ & $59 \pm 18,2$ & 0,93 & 0,77 \\
\hline Настрій & $65,3 \pm 19$ & $65,4 \pm 12,4$ & $75 \pm 15,1$ & $76,7 \pm 6,4$ & 0,03 & $<0,001$ \\
\hline Занепокоєння & $68,1 \pm 14,7$ & $70 \pm 0$ & $72,1 \pm 15,1$ & $74,1 \pm 10,5$ & 0,26 & 0,06 \\
\hline Загальні питання: А & $53,2 \pm 14,1$ & $52 \pm 6,9$ & $55,9 \pm 12,4$ & $53,4 \pm 11$ & 0,45 & 0,54 \\
\hline B & $53,5 \pm 9,5$ & $52,8 \pm 9,8$ & $55,3 \pm 8,6$ & $55,2 \pm 8,7$ & 0,44 & 0,35 \\
\hline
\end{tabular}

Примітка: А - У порівнянні з місяцем до того, як у Вас виявили рак, як би Ви оцінили стан здоров'я? В - Як би Ви оцінили стан Вашого здоров'я протягом останніх 7 днів? C - Загальна якість життя протягом останніх 7 днів. 


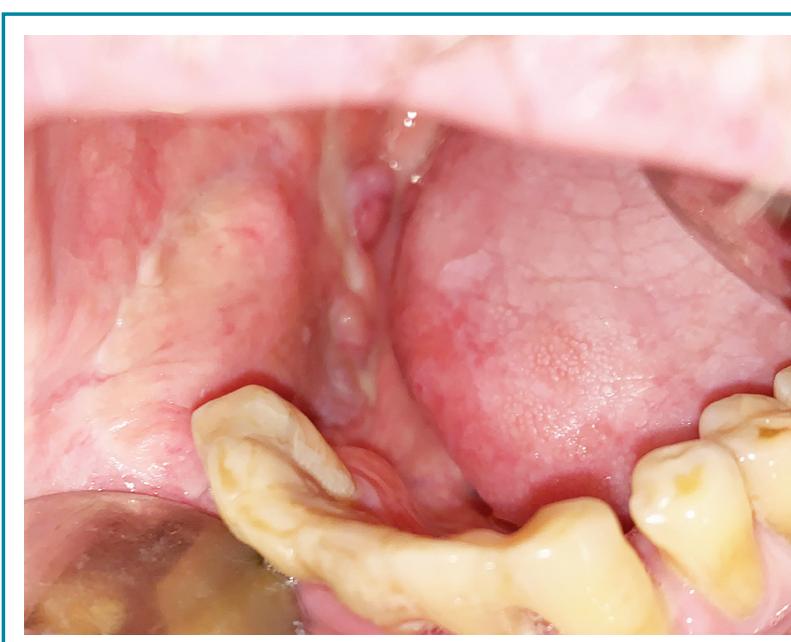

Рис. 3. Пластичне усунення середнього дефекту щоки модифікованим ШМКП

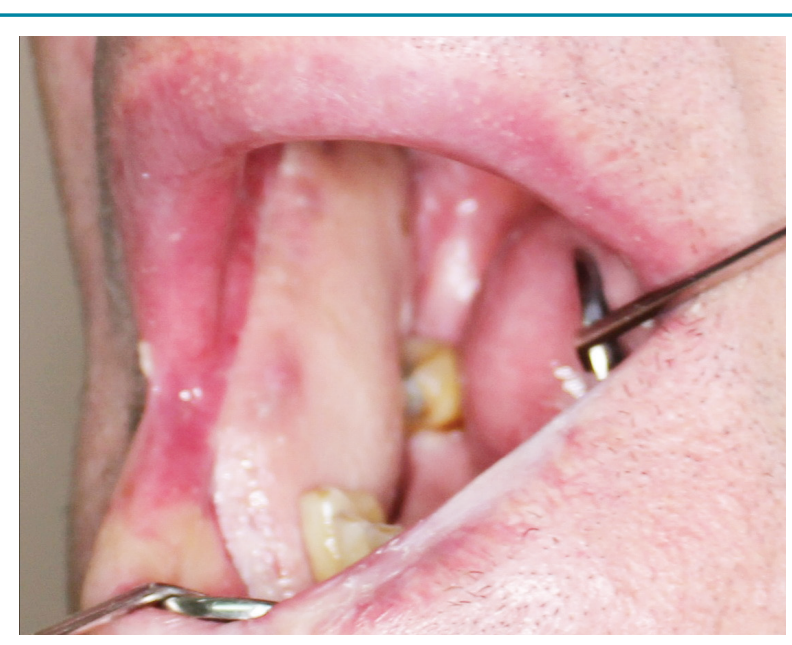

Рис. 4. Пластичне усунення великого дефекту щоки модифікованим КНА

Таблиця 3. Якість життя пацієнтів через 6 та 12 міс після хірургічного лікування

\begin{tabular}{|c|c|c|c|c|c|c|}
\hline \multirow{3}{*}{$\begin{array}{c}\text { Якість життя } \\
\text { за опитувальником } \\
\text { UW-QOL v4,\% }\end{array}$} & \multicolumn{4}{|c|}{$\overline{\mathrm{X}} \pm \mathbf{S D}$} & \multirow{2}{*}{\multicolumn{2}{|c|}{$\begin{array}{c}\text { Рівень значимості відмінності між } \\
\text { групами, p }\end{array}$}} \\
\hline & \multicolumn{2}{|c|}{ Група ФК } & \multicolumn{2}{|c|}{ Група ШК } & & \\
\hline & $\begin{array}{c}\text { Через } 6 \text { міс } \\
(n=26)\end{array}$ & $\begin{array}{c}\text { Через } 12 \text { міс } \\
(n=23)\end{array}$ & $\begin{array}{c}\text { Через } 6 \text { мic } \\
(n=30)\end{array}$ & $\begin{array}{c}\text { Через } 12 \text { міс } \\
(n=27)\end{array}$ & Через 6 міс & Через 12 міс \\
\hline Біль & $75 \pm 20$ & $76,1 \pm 19,2$ & $81,7 \pm 18,5$ & $84,3 \pm 18,5$ & 0,21 & 0,12 \\
\hline Зовнішній вигляд & $71,2 \pm 26,2$ & $72,8 \pm 27,1$ & $80,8 \pm 10,8$ & $82,4 \pm 11,6$ & 0,24 & 0,37 \\
\hline Активність & $78,8 \pm 18,3$ & $83,7 \pm 16,2$ & $81,7 \pm 17,3$ & $85,2 \pm 15,9$ & 0,57 & 0,74 \\
\hline Відпочинок & $76 \pm 16,6$ & $79,3 \pm 19,4$ & $77,5 \pm 17,8$ & $81,5 \pm 16,4$ & 0,72 & 0,75 \\
\hline Ковтання & $95,2 \pm 10$ & $97,8 \pm 7,2$ & $97,5 \pm 7,6$ & $97,2 \pm 8$ & 0,33 & 0,78 \\
\hline Жування & $53,8 \pm 28$ & $52,2 \pm 31,9$ & $70 \pm 24,9$ & $72,2 \pm 25,3$ & 0,03 & 0,03 \\
\hline Мова & $91,9 \pm 13,6$ & $96,1 \pm 10,3$ & $92 \pm 13,5$ & $93,3 \pm 12,7$ & 0,98 & 0,4 \\
\hline Плече & $83,8 \pm 15,3$ & $80 \pm 18,3$ & $77 \pm 12,9$ & $75,6 \pm 11,9$ & 0,07 & 0,2 \\
\hline Смак & $57,7 \pm 18,8$ & $67,8 \pm 13,5$ & $51,3 \pm 20,3$ & $68,1 \pm 12,4$ & 0,23 & 0,95 \\
\hline Слина & $46,9 \pm 20,2$ & $66,5 \pm 11,5$ & $47,3 \pm 20,2$ & $65,6 \pm 12,8$ & 0,94 & 0,78 \\
\hline Настрій & $66,3 \pm 17,2$ & $66,3 \pm 14,3$ & $72,5 \pm 15,2$ & $73,1 \pm 16,9$ & 0,13 & 0,15 \\
\hline Занепокоєння & $50,8 \pm 24,2$ & $55,2 \pm 24,1$ & $68,3 \pm 20,7$ & $75,9 \pm 19,1$ & 0,006 & 0,002 \\
\hline Загальні питання: А & $50 \pm 15,8$ & $51,1 \pm 17,6$ & $56,7 \pm 17,3$ & $57,4 \pm 11,6$ & 0,13 & 0,19 \\
\hline B & $53,1 \pm 13,8$ & $53,9 \pm 15,3$ & $58,7 \pm 12,8$ & $58,5 \pm 12,3$ & 0,14 & 0,26 \\
\hline C & $55,4 \pm 13$ & $56,5 \pm 15,6$ & $62 \pm 16,1$ & $63 \pm 15,4$ & 0,12 & 0,16 \\
\hline
\end{tabular}

Примітка: А - У порівнянні з місяцем до того, як у Вас виявили рак, як би Ви оцінили стан здоров'я? В - Як би Ви оцінили стан Вашого здоров'я протягом останніх 7 днів? С - Загальна якість життя протягом останніх 7 днів

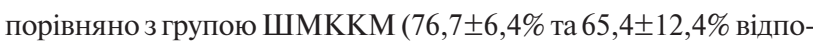
відно); вірогідно ( $p=0,01)$ вище значення показника загальної якості життя у хворих групи ШМКВГМ порівняно з групою

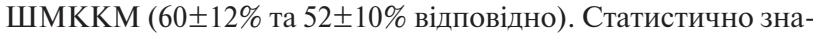
чущих відмінностей за показниками болю, активності, відпочинку, мови, плеча, смаку, слини, занепокоєння та загальних питань (стану здоров'я) опитувальника UW-QOL v4 між групами хворих не встановлено ( $>>0,05$ для всіх порівнянь) (табл. 2).

Пластичне заміщення дефектів слизової оболонки щоки. Статистично значущих відмінностей між групою ФК та групою ШК за віком, статтю, локалізацією, типом дефекту, TNM, стадією захворювання, ад'ювантним лікуванням не встановлено ( $>00,05$ для всіх порівнянь).

У дослідженні встановлено вірогідно $(\mathrm{p}=0,007)$ вищий функціональний результат за показником повноцінності дієти шкали PSS-HN через 12 міс після хірургічного лікування у хворих групи ШК порівняно з групою ФК $(71,9 \pm 14,4 \%$ та $61,7 \pm 15 \%$, відповідно). Статистично значущих відмінностей за показниками харчування на людях та зрозумілості мови шкали PSS-HN між групами хворих не виявлено ( $>0,05$ для обох порівнянь). Результати пластичного усунення середнього та великого дефектів щоки модифікованим ШМКП та КНА представлено на рис. 3, 4 .

При проведенні порівняльного аналізу якості життя за опитувальником UW-QOL v4 через 12 міс після хірургічного лікування було виявлено вірогідно $(\mathrm{p}=0,03)$ вище значення показника жування у хворих групи ШК порівняно з групою ФК (72,2 $25,3 \%$ та $52,2 \pm 31,9 \%$, відповідно) та вірогідно $(\mathrm{p}=0,002)$ вище значення показника занепокоєння у хворих групи ШК порівняно з групою ФК $(75,9 \pm 19,1 \%$ та 55,2 $24,1 \%$ відповідно). Статистично значущих відмінностей за показниками болю, зовнішнього вигляду, активності, відпочинку, мови, плеча, смаку, слини, настрою та загальних питань опитувальника UW-QOL v4 між групами хворих не встановлено ( $>00,05$ для всіх порівнянь) (табл. 3).

\section{ВИСНОВКИ}

1. Застосування модифікованого ШМКП для пластичного усунення поверхневих дефектів дна ротової порожнини достовірно покращує функціональний результат за показниками повноцінності дієти і харчування на людях та якість життя хворих за показниками зовнішнього вигляду і жування у порівнянні із застосуванням локального НГК.

2. Застосування регіонарного модифікованого ШМКВГМ для пластичного усунення глибоких дефектів дна ротової порожнини достовірно покрашує функціональний результат за показниками повноцінності дієти та харчування на людях; якість життя хворих за показниками зовнішнього вигляду, жування, настрою та загальної якості життя у порівнянні із застосуванням ШМККМ.

3. Застосування ШК для пластичного заміщення дефектів слизової щоки достовірно покращує функціональний результат за показником повноцінності дієти; якість життя хворих за показниками жування і занепокоєння у порівнянні із застосуванням ФК.

Конфлікт інтересів: відсутній.

Усі процедури проведеного дослідження затверджені комісією з питань етики Національного інституту раку. 


\section{СПИСОК ВИКОРИСТАНОї ЛІТЕРАТУРИ}

1. Spiotto, M. T., Jefferson, G., Wenig, B., Markiewicz, M., Weichselbaum, R. R., \& Koshy, M. (2017). Differences in survival with surgery and postoperative radiotherapy compared with definitive chemoradiotherapy for oral cavity cancer. A national cancer database analysis Otolaryngology-Head and Neck Surgery, 143(7), 691-699. doi: 10.1001/jamaoto.2017.0012 2. Bussu, F., Gallus, R., Navach, V., Bruschini, R., Tagliabue, M., Almadori, G., Calabrese, L. (2014). Contemporary role of pectoralis major regional flaps in head and necksurgery. Acta otorhinolaryngologica Italica, 34(5), 327-341.

3. Huang, L., Gao, X., Su, T., Jiang, C. H., \& Jian, X. C. (2018). Vertical platysma myocutaneous flap reconstruction for oral defects using three different incision designs: experience with 68 cases. International Journal of Oral and Maxillofacial Surgery, 47(3): 324-329. doi: 10.1016/j.ijom. 2017.07.017.

4. Lazaridou, M., Vaxtsevanos, K., Dimitrakopoulos, I., Lazaridis, N., \& Antoniades, K. (2016). Nasolabial pedicled compared with island flaps for intraoral reconstruction of oncological defects: complications, recovery of sensitivity, and assessment of quality of life. British Journal of Oral and Maxillofacial Surgery, 54(7): 746-750. doi: 10.1016/.j.bjoms.2016.04.017.

5. Jones, L. F., Farrar, E. M., Roberts, D. J. H., \& Moor, J. W. (2019). Revisiting the sternocleidomastoid flap as a reconstructive option in head and neck surgery. The Journal of Laryngology \& Otology, 133(9): 742-746. doi: 10.1017/S0022215119001592.

6. Sen, S., Gagagowni, J. G., Pandey, J. K., Dasgupta, P., Sahni, A., Gupta, S. Ravi, B. (2019). Effectiveness of pectoralis major myocutaneous flap in the surgical management of oral cancer: A retrospective study. Journal of Stomatology, Oral and Maxillofacial Surgery, 120(1): 21-27. doi: 10.1016/j.jormas.2018.08.003.

7. Granzow, J. W., Suliman, A., Roostaeian, J., Perry, A., \& Boyd, J. B. (2013). The supraclavicular artery island flap (SCAIF) for head and neck reconstruction: surgical technique and refinements. Otolaryngology-Head and Neck Surgery, 148(6): 933-940. doi: 10.1177/0194599813476670.

8. Bhambar, R. S., Baliga, M., Kumar, A., Jagannathan, S., Kumar, H., Kumar, R. Singh, H. P. (2016). Revisit of Nasolabial flap in the reconstruction of defects involving the oral floor. Nigerian Journal of Surgery, 22(1): 21-25. doi: 10.4103/1117-6806.172222.

9. Mannelli, G., Arcuri, F., Comini, L. V., Valente, D. \& Spinelli, G. (2019). Buccal Fat Pad: Report of 24 Cases and Literature Review of 1,635 Cases of Oral Defect Reconstruction. Journa for Oto-Rhino-Laryngology, Head and Neck Surgery, 81 (1), 24-35. doi: 10.1159/000494027.

10. Perez, E., Maliakal, C., Dinh, C., \& Sargi, Z. T(2019). The pedicled temporoparieta fascial flap. Operative Techniques in Otolaryngology-Head and Neck Surgery, 30(2): 127-133. doi: 10.1016/j.otot.2019.04.007

11. Welz, C., Canis, M., Schwenk-Zieger, S., Spiegel, J. L., Weiss, B. G., \& Pilavakis, Y. (2017). Oral Cancer Reconstruction Using the Supraclavicular Artery Island Flap: Comparison to Free Radial Forearm Flap. Journal of Oral and Maxillofacial Surgery, 75(10) 2261-2269. doi: 10.1016/j.joms.2017.02.017.

12. Hwang, D. S., Park, J., Kim, U. K., Park, H. R., Kim, G. C., \& Ryu, M. H. (2018). Reconstruction of cheek mucosal defect with a buccal fat pad flap in a squamous cell carcinoma patient: a case report and literature review. Maxillofacial Plastic and Reconstructive Surgery 40(1), 11. doi: 10.1186/s40902-018-0150-8.

13. Long. H., Xinchun. J., Xinqun. C., Tong. S., \& Canhua. J. (2017). Application of muscle pedicled platysma myocutaneous flap in the reconstruction of buccal mucosa defects. West China Journal of Stomatology, 35(2), 162-166. doi: 10.7518/hxkq.2017.02.010.

14. Chen. H. C., \& Chang. H. S. (2015). The sternocleidomastoid flap for oral cavity reconstruction: Extended indications and technical modifications. Journal of Oral and Maxillofacial Surgery, 73(12), 2429-2439. doi: 10.1016/j.joms.2015.07.027.

Реконструктивно-восстановительные операции

у больных с местно-распространенным плоскоклеточным раком слизистой оболочки дна ротовой полости и щеки

О.В. Кравец, О.О. Колесник, В.В. Черниенко, О.В. Хлынин Национальный институт рака, Киев

Резюме. Цель. Сравнить функциональный результат и качество жизни больных с местно-распространенным плоскоклеточным раком ротовой полости при применении различных реконструктивно-восстановительных методикдля замещения послеоперационных дефектов дна полости рта и щеки. Материалы и методы. Проведен сравнительный анализ результатов оперативных вмешательств, выполненных 150 пациентам с местно-распространенным плоскоклеточным раком слизистой оболочки дна полости рта и щеки. Типы дефектов после удаления первичной опухоли: поверхностный дефект дна ротовой полости у 29 больных, глубокий дефект дна ротовой полости у 65 , средний и большой дефекты слизистой оболочки щеки - у 56 пациентов. Результаты. В случае пластического замещения поверхностных дефектов дна полости рта установлено достоверно $(\mathrm{p}=0,006)$ более высокий функциональный результат по показателю полноценности диеты в группе больных, у которых был применен кожно-мышечный лоскут платизмы по сравнению с группой больных, у которых использовали носогубной лоскут $(75,7 \pm 13,4 \%$ и $60,8 \pm 9,0 \%$ соответственно) и по показателю питания на людях ( $\mathrm{p}=0,04)$ в группе больных, у которых использовали кожно-мышечный лоскут платизмы по сравнению с группой носогубного лоскута $(80,4 \pm 14,5 \%$ и $68,8 \pm 11,3 \%$ соответственно). В случае пластического замещения глубоких дефектов дна полости рта установлено достоверно $(\mathrm{p}<0,001)$ более высокий функциональный результат по показателю полноценности диеты в группе больных, у которых был использован кожно-мышечный лоскут болышой грудной мышщы по сравнению с группой больных, у которых применяли кожно-мышечный лоскут кивательной

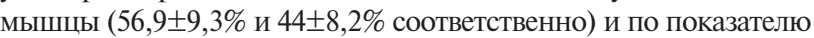
питания на людях $(\mathrm{p}=0,005)$ у больных группы кожно-мышечного лоскута болышого грудной мышщы по сравнению с группой кожно-

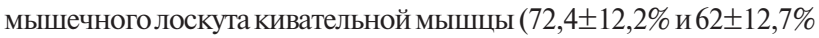
соответственно). В случае пластического замешения дефектов слизистой оболочки щеки установлено достоверно $(\mathrm{p}=0,007)$ более высокий функциональный результат по показателю полноценности диеты в группе больных, у которой использовали кожные лоскуты по сравнению с группой больных, у которых применяли

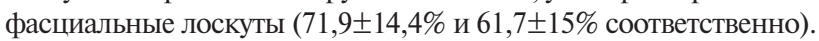
Bыводы. Определены наиболее эффективные реконструктивно-восстановительные методики для пластического замещения послеоперационных поверхностных и глубоких дефектов дна полости рта и щеки.

Ключевые слова: местно-распространенный плоскоклеточный рак слизистой дна ротовой полости и щеки; реконструктивно-восстановительное лечение; лоскуты.

Reconstructive and restorative techniques to replace postoperative defects of the oral cavity and cheek in patients with locally advanced squamous cell carcinoma

\section{O.V. Kravets, O.O. Kolesnik, V.V. Cherniienko, O.V. Khlynin} National Cancer Institute, Kyiv

Summary. Objective. To compare the functional outcome and quality of life of patients with locally advanced squamous cell carcinoma of the oral cavity using various reconstructive and restorative techniques to replace postoperative defects of the oral cavity and cheek. Materials and Methods. There was conducted a comparative analysis of the results of surgical interventions performed in 150 patients with locally advanced squamous cell carcinoma of the floor of the mouth and buccal mucosa. The analysis revealed the following types of postoperative defect after primary tumor removal: superficial defect of the oral cavity was present in 29 patients, deep defect of the oral cavity was found in 65 patients, while medium and large defects of the buccal mucosa were present in 56 cases. Results. In the case of plastic replacement of superficial defects of the oral cavity, there was found a significantly $(p=0.006)$ higher functional result in terms of the fortified diet in the group of patients who received the platysma myocutaneous flap compared with the group of patients who received the nasolabial flap $(75.7 \pm 13.4 \%$ and $60.8 \pm 9.0 \%$, respectively), and in the terms of human nutrition ( $\mathrm{p}=0.04$ ) in the group of patients with platysma myocutaneous flap compared with the group of nasolabial flap $(80.4 \pm 14.5 \%$ and $68.8 \pm 11.3 \%$, respectively). In the case of plastic replacement of deep defects of the oral cavity, a significantly $(p<0.001)$ higher functional result was found in terms of the fortified diet in the group of patients who received the pectoralis major myocutaneous flap compared with the group of patients who receive the supraclavicular artery island flap $(56.9 \pm 9.3 \%$ and $44 \pm 8.2 \%$, respectively), and in the terms of human nutrition $(\mathrm{p}=0.005)$ in the group of patients with pectoralis major myocutaneous flap compared with the group of supraclavicular artery island flap $(72.4 \pm 12.2 \%$ and $62 \pm 12.7 \%$, respectively). In the case of plastic replacement of defects of the buccal mucosa, a significantly ( $p=0.007$ ) higher functional result was found in terms of the fortified diet in the group of patients who received the skin flaps compared with the group of patients who received the fascial flaps (71.9 $\pm 14,4 \%$ and $61.7 \pm 15 \%$, respectively). Conclusions. There were determined the most effective reconstructive and restorative techniques for plastic replacement of the postoperative superficial and deep defects of the oral cavity and cheek.

Keywords: locally advanced squamous cell carcinoma of the floor of the mouth and buccal mucosa; reconstructive and restorative treatment; flaps.

Адреса:

Черніснко Віктор

03022, Київ, вул. Ломоносова, 33/43

Національний інститут раку

E-mail: viktor.cherniienko@gmail.com Correspondence: Cherniienko Viktor 33/43 Lomonosov Str., Kyiv 03022 National Cancer Institute E-mail: viktor.cherniienko@gmail.com 